\title{
COMPARISON OF THE LEVEL OF EXPRESSION OF PROLIFERATION MARKERS KI-67 AND CYCLIN D1 IN TRIPLE-NEGATIVE BREAST CANCER WITH DIFFERENT ANDROGENIC STATUS
}

\author{
Vashchenko L.N., Karnaukhov N.S., Gudtskova T.N., Kvarchiya M.V. \\ Aims.
}

The research was aimed at a comparative study of the expression levels of Ki-67 and cyclin D1 in subtypes of triple-negative breast cancer (TNBC) with varying androgenic status.

Materials and methods.

Surgical material was studied from 60 patients of clinical group 2A, clinical stage T1-2N0M0, treated at Rostov Research Institute of Oncology, from 2012 to 2015. In all cases, the surgery was the first stage of treatment. Antibodies to estrogen, progesterone, and androgen receptors, cytokeratin 5/6, Ki-67, cyclin D1, and proteins HER2/neu and EGFR were used for the immune histochemical test.

Results.

It was found that a significantly higher level of Ki-67 expression was observed in TNBC with signs of basal epithelium in comparison with other TNBC, however, the level of cyclin D1 expression was inconclusive. Overexpression of cyclin D1 was observed in the part of TNBC that had no correlation with the Ki-67 expression level. High levels of cyclin D1 in the basal-like TNBC was less frequent than in TNBC without signs of basal epithelium, but its mean value was significantly higher. The level of Ki-67 did not differ significantly in TNBC with different androgenic status. Overexpression of cyclin D1 was more common among androgen-positive TNBC, and its mean value was significantly higher compared to the androgen-negative tumor.

Conclusions.

Ki-67 proliferation marker and cyclin D1 cell cycle regulator can be used as additional criteria for monitoring the course of TNBC subtypes.

Keywords: triple-negative breast cancer (TNBC), basal-like triple-negative breast cancer, Ki-67, cyclin D1, androgen receptors.

\section{INTRODUCTION.}

Breast cancer (BC) occupies the leading place in the structure of oncopathology in women worldwide. Annually, one million cases of BC are registered with the lethality of more than 520 thousand patients [1].

The rate of triple-negative breast cancer (TNBC) is $10-20 \%$ of all the breast tumors. These are aggressive tumors with quick metastasis development that are characterized by an unfavorable prognosis [2].

Success in the treatment and prognosis of BC directly depends on the proper and timely morphological, immunohistochemical, and molecular-genetic diagnostics of this disease [3, 4].

Because of the lack of all three standard targets for target therapy in TNBC cells (estrogen receptors (ER), progesterone receptors (PR), and HER2/neu-receptors), there is still no specialized treatment for these tumors, except for chemotherapy that affects all the dividing cells $[2,5]$.

During the past years, numerous works were published that provide evidence that TNBC is a heterogeneous type that includes from 3 to 5 subtypes. However, the criteria for these subtypes are quite controversial $[3,4,6]$.

A basal-like subtype of TNBC is diagnosed in $70 \%$ of TNBC cases. Researchers in their studies propose different markers for the identification of this subtype of BC: EGFR, highmolecular basal cytokeratins (CK5/6, CK14, CK17), c-KIT, NGFR, p63 proteins, laminin, osteonectin, vimentin, and others [3, 6-8]. However, there is still no unified standard.

There are suggestions on possible differences in the tactics of treatment of TNBC subtypes. 
The search for potential targets for target therapies of TNBC subtypes by the identification of significant biological markers and transfer to the personified treatment of this category of patients and improvement of the treatment results is acute nowadays [5-8].

Lately, the researchers have focused on the preservation of androgen receptors (AR) in ER and PR negative BC. It was revealed that in TNBC AR can remain. However, the data on the share of such tumors varies greatly from 10 to $43 \%$. There is no definite opinion on the prognostic significance of this marker $[9 ; 10]$.

$\mathrm{Ki}-67$ is a nuclear protein that is associated with cellular proliferation and expresses in the phases of cellular mitotic cycles S, G1, G2, and M, except for G0. It is also expressed in the samples of normal mammal tissue but at a low level (less than $3 \%$ of cells). The level of expression of Ki-67 determines the tactics of adjuvant treatment for patients with BC. TNBC is characterized by hyperexpression of the marker of proliferation Ki-67.

Biomarkers that are involved in the regulation of mitosis attract researchers' interest. In particular, cyclins, cyclin-dependent kinases, and cyclin-dependent kinase inhibitors play the most important role in the development of the cellular cycle. The most relevant biomarker is the regulator of the cellular cycle cyclin D1. Increased production of cyclin D1 contributes to the initiation of cellular mitosis. The data on the level of expression of cyclin D1 are scarce and controversial [11-13].

The study was aimed to evaluate the levels of expression of Ki-67 and cyclin D1 in patients with basal-like and nonbasal-like TNBC with the presence and absence of androgen receptors in the tumor.

\section{MATERIALS AND METHODS.}

The material for the present study was operational material obtained from 60 patients with TNBC that were treated at the Rostov Research Institute of Oncology, from 2012 to 2015.

The patients were in clinical group 2A, T1-2N0M0 (by the results of mammography, breast ultrasonography, chest, thoracic and pelvic SCT). In all the cases, the surgery was the first stage of the treatment. The age of patients varied from 29 to 71 years old. Since there were 40 patients $(66.7 \%)$ aged $41-60$, the mean age of patients was $51.3 \pm 3.5$ years old.

Based on the standard immunohistochemical (IHC) study, all the patients were diagnosed TNBC (ER-/PR-/Her2-negative) and had the level of Ki-67 measured. Additionally, the expression of AR and cyclin D1 was evaluated.

For the IHC study, 3-4- $\mu \mathrm{m}$ sections were prepared from the paraffin blocks of the specimens and stained in the immunohistostainer BenchMark ULTRA. The data on the used antibodies are presented in Table 1. 


\begin{tabular}{|l|l|c|c|c|l|}
\hline No. & \multicolumn{1}{|c|}{ Antibody } & Clone & Producer & Dilution & Retrieval \\
\hline 1. & ER & SP1 & $\begin{array}{c}\text { Thermo } \\
\text { Scientific }\end{array}$ & $1: 300$ & $\begin{array}{l}\text { Tris buffer } \\
\text { PH=8.0-8.5 }\end{array}$ \\
\hline 2. & PR & SP2 & Cell Marque & $1: 200$ & Citric PH=6 \\
\hline 3. & AR & AR441 & Dako & $1: 200$ & Tris PH=8.0-8.5 \\
\hline 4. & Ki-67 & SP6 & Spring Bio & $1: 200$ & Tris PH=8.0-8.5 \\
\hline 5. & HER2/neu & 4 B5 & Roche & RTU & Tris PH=8.0-8.5 \\
\hline 6. & Cyclin D1 & EP12 & Dako & $1: 200$ & Tris PH=8.0-8.5 \\
\hline 7. & CK 5/6 & D5/6BH & Dako & $1: 200$ & Tris PH=8.0-8.5 \\
\hline 8. & EGFR & $($ E30 $)$ & Dako & $1: 50$ & Proteinase I \\
\hline
\end{tabular}

For the characteristics of the expression of Ki-67, AR, and cyclin D1, the share of cells with stained nuclei was calculated in percent from the total tumor cell count. Androgen-positive (AR+) tumors were tumors with the expression $\geq 10 \%$ of tumor cells and androgen-negative (AR-) - with the expression $<10 \%$ of tumor cells.

The statistical analysis of the obtained data included parametric methods of statistics for variation rows: arithmetic mean $(\mathrm{M})$, the error of the mean $(\mathrm{m})$, median $(\mathrm{Me})$, and the variation coefficient (C.V.). The significance of the difference between the two mean values was evaluated by Student's t-test. The correlations were established with Pierson's correlation coefficient (r).

The study protocol followed guidelines for experimental investigation with human subjects in accordance with the Declaration of Helsinki and was approved by the ethics committee. Written informed consent was obtained from each patient (or official representative) before the study.

RESULTS. Based on the results of the IHC study with antibodies to CK5/6 and EGFR, all TNBC types were distributed as follows: basal characteristics were revealed in 37 patients $(61.7 \%)$ (BL TNBC) and lacked in 23 patients (38.3\%), the latter we called non-classified (NC TNBC) (Table 2).

Table 2. The level of expression of Ki-67 and cyclin D1 in TNBC

\begin{tabular}{|c|c|c|c|}
\hline \multirow[t]{2}{*}{$\begin{array}{c}\text { Group of TNBC } \\
\text { abs. }(\%)\end{array}$} & \multicolumn{2}{|c|}{$\begin{array}{l}\text { The level of } \\
\text { expression of IHC- } \\
\text { marker }(\mathrm{M} \pm \mathrm{m}, \%)\end{array}$} & \multirow[t]{2}{*}{$\begin{array}{l}\text { Correlation } \\
\text { coefficient (r) }\end{array}$} \\
\hline & $\mathrm{Ki}-67$ & Cyclin D1 & \\
\hline $\begin{array}{c}\text { Total: } \\
\mathrm{n}=60(100 \%)\end{array}$ & $\begin{array}{c}76.4 \pm 2.2 \\
\mathrm{Me}=80 \\
\text { C.V. }=20.4\end{array}$ & $\begin{array}{c}35.4 \pm 5.1 \\
\mathrm{Me}=20 \\
\mathrm{C} . \mathrm{V} .=99.5\end{array}$ & 0.12 \\
\hline $\begin{array}{c}\text { Basal-like (BL) } \mathrm{n}=37 \\
(61.7 \%)\end{array}$ & $\begin{array}{c}81.9 \pm 3.1 \bullet \\
\mathrm{Me}=85 \\
\text { C.V. }=18.1\end{array}$ & $\begin{array}{c}38.1 \pm 8.1 \\
M e=22.5 \\
\text { C.V. }=102.5 \\
\end{array}$ & 0.084 \\
\hline $\begin{array}{c}\text { Non-classified (NC) } \\
n=23(38.3 \%)\end{array}$ & $\begin{array}{c}70.8 \pm 3.1 \bullet \\
\mathrm{Me}=75 \\
\text { C.V. }=21.1\end{array}$ & $\begin{array}{c}32.8 \pm 6.5 \\
M e=20 \\
\text { C.V } .=99.2\end{array}$ & 0.117 \\
\hline
\end{tabular}


Note: C.V. - variation coefficient, $\mathrm{Me}-$ median. The difference between the parameters marked with $\bullet$ is significant $(\mathrm{P} \leq 0.05)$.

In general, in patients with TNBC, the level of $\mathrm{Ki}-67$ was $76.4 \pm 2.2 \%(\mathrm{Me}=80, \mathrm{C} . \mathrm{V} .=20.4)$. The mean level of Ki-67 in TNBC was significantly higher than in NC TNBC $(81.9 \pm 3.1 \%$ and $70.8 \pm 3.1 \%$, respectively $(\mathrm{P}<0.05))$. In both groups, the distribution of data by this parameter was insignificant with variance coefficients $<30$ (Table 2).

The mean level of the expression of cyclin D1 in TNBC was 35.4 \pm 5.1 . The difference in the expression of cyclin D1 in BL TNBC and NC TNBC (38.1 \pm 8.1 and $32.8 \pm 6.5 \%$, respectively) was insignificant. The medians were also close (22.5 and 20, respectively) (Table 2). The performed correlation analysis between the levels of expression of $\mathrm{Ki}-67$ and cyclin $\mathrm{D} 1$ revealed an insignificant correlation between these quantitative parameters (Table 2).

It should be mentioned that, in general, the variation coefficient was high: around $100 \%$ in both TNBC groups, which indicated high variability of the level of expression of cyclin D1 (Table 2). Factually, in the studied patients with TNBC, the level of expression of cyclin D1 varied from $1 \%$ to nearly $100 \%$ of the stained nuclei. For this reason, the authors divided the group into two subgroups: with a high and low level of expression of cyclin D1. The threshold level of cyclin D1 was taken for $30 \%$ because, earlier, such ranking was met in other publications [10]. The data are presented in Table 3.

Table 3. Expression of cell cycle markers in the subgroups TNBC with a low and high level of cyclin D1.

\begin{tabular}{|c|c|c|c|c|}
\hline \multirow{2}{*}{\multicolumn{2}{|c|}{$\begin{array}{c}\text { Group TNBC, } \\
\text { abs. }(\%)\end{array}$}} & \multirow{2}{*}{$\begin{array}{c}\text { Subgroup of TNBC by } \\
\text { the level of cyclin D1, } \\
\text { abs. }(\%)\end{array}$} & \multicolumn{2}{|c|}{$\begin{array}{l}\text { The level of expression } \\
\text { of IHC-marker }(\mathrm{M} \pm \mathrm{m}, \%)\end{array}$} \\
\hline & & & Cyclin D1 & Ki-67 \\
\hline \multirow{6}{*}{ 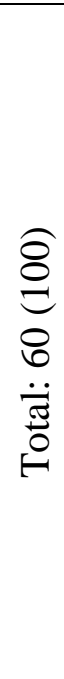 } & \multirow[t]{3}{*}{ Basal-like 37 (61.7) } & $\begin{array}{l}\text { High } \\
12(32.4)\end{array}$ & $\begin{array}{r}89.9 \pm \mathbf{4 . 7} \mathbf{\Delta} \\
\mathrm{Me}=92 \\
\text { C. V. }=13.8\end{array}$ & $\begin{array}{r}83.3 \pm 4.7 \bullet \\
\mathrm{Me}=85 \\
\text { C. V. }=18.2\end{array}$ \\
\hline & & $\begin{array}{l}\text { Low } \\
25(67.6)\end{array}$ & $\begin{array}{r}12.2 \pm \mathbf{2 . 8} \\
\mathrm{Me}=10 \\
\text { C. } \mathrm{V} .=89.3\end{array}$ & $\begin{array}{r}81.3 \pm 3.9 \\
M e=85 \\
\text { C. } V .=18.6\end{array}$ \\
\hline & & \multicolumn{3}{|l|}{ Total: $37(100)$} \\
\hline & \multirow{3}{*}{ Non-classified 23 (38.3) } & $\begin{array}{l}\text { High } \\
10(43.5)\end{array}$ & $\begin{array}{r}66.5 \pm 6.6 \Delta \\
M e=70 \\
\text { C. V. }=29.9 \\
\end{array}$ & $\begin{array}{r}70.1 \pm 3.6 \bullet \\
\mathrm{Me}=70 \\
\text { C. V. }=21.1\end{array}$ \\
\hline & & $\begin{array}{l}\text { Low } \\
13(56.5)\end{array}$ & $\begin{array}{r}8.6 \pm 2.7 \\
M e=5 \\
\text { C. } V .=110.5\end{array}$ & $\begin{array}{r}75 \pm 4.1 \\
\mathrm{Me}=80 \\
\text { C. } \mathrm{V} .=19.7\end{array}$ \\
\hline & & Total: 23 (100) & & \\
\hline
\end{tabular}

Note: C.V. - variation coefficient, $\mathrm{Me}-$ median. The difference in the parameters marked with the same symbols $(\boldsymbol{\Lambda}$ or -) is significant $(\mathrm{P}<0.05)$. 
TNBC, it was observed in $32.4 \%$ of cases, in patients with NC TNBC, it was observed in $43.5 \%$ of cases. The mean level of expression of this marker was significantly higher $(\mathrm{P} \leq 0.05)$ in patients with BL TNBC $(89.9 \pm 4.7 \%)$ than in patients with NC TNBC (66.5 $\pm 6.6 \%)$ (median $-92 \%$ and $70 \%$, respectively) (Table 3). In both groups, the variance coefficients were <30, which indicated the consistency of the studied rows of data.

The expression of Ki-67 in patients with BL TNBC with a high level of cyclin D1 was $83.3 \pm 4.7 \%$ and in patients with $\mathrm{MC}$ TNBC $-70.1 \pm 3.6 \%$ (median 85 and $70 \%$, respectively), the difference was significant $(\mathrm{P}<0.05)$. A low level of variation $(<30)$ indicated the relative consistency of the obtained data (Table 3).

A low level of cyclin D1 in patients with BL TNBC was $12.2 \pm 2.8 \%$ and NC TNBC $8.6 \pm 2.7 \%$. The difference in the parameters was not significant because of the high variability of data in both subgroups (the variation coefficient 89.3 and 110.5, respectively). The mean level of expression of Ki-67 between the subgroups with a low level of cyclin D1 did not differ statistically and was $81.3 \pm 39 \%$ in BL TNBC and $75 \pm 4.1 \%$ in NC TNBC ( $>0.05)$.

In other words, a high level of expression of cyclin D1 in BL TNBC was met several times rarer, but its mean level was significantly higher by $23.4 \%$ than in TNBC without the signs of the basal epithelium $(\mathrm{p}<0.05)$.

$\mathrm{AR}+$ tumors were observed in 11 cases (18.3\%), the mean expression of AR was $51.6 \pm 3.4 \%, \mathrm{Me}=71.9 \%$. It can be noted that in 5 tumors, expression of AR was $10-30 \%$, in the rest cases - from $80-95 \%$, i.e. when the expression of AR was either low or high, there were no mean values in the range $>30 \%$ but $<80 \%$. The AR-status was established in 49 tumors $(81.7 \%)$. The ratio between TNBC with signs of basal epithelium and without them was similar in AR+ and ARtumors (Table 4).

The results on AR levels in the studied patients with TNBC are presented in Table 4.

Table 4. Expression of Ki-67 and cyclin D1 in TNBC with different androgen status.

\begin{tabular}{|c|c|c|c|c|c|}
\hline \multirow{2}{*}{\multicolumn{2}{|c|}{$\begin{array}{l}\text { AR-status } \\
\text { of the } \\
\text { tumor, } \\
\text { abs. }(\%)\end{array}$}} & \multicolumn{2}{|c|}{ Group of TNBC, abs. (\%) } & \multicolumn{2}{|c|}{$\begin{array}{l}\text { The level of expression } \\
\text { of IHC-marker }(\mathrm{M} \pm \mathrm{m} \text {, } \\
\%)\end{array}$} \\
\hline & & $\mathrm{BL}$ & $\mathrm{NC}$ & $\mathrm{Ki}-67$ & cyclin D1 \\
\hline \multirow{4}{*}{ 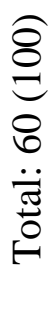 } & \multirow{2}{*}{$\begin{array}{c}\mathrm{AR}+ \\
\mathrm{n}=11(18.3)\end{array}$} & $7(63.6)$ & $4(36.4)$ & \multirow{2}{*}{$\begin{array}{c}68.9 \pm 6.4 \\
\mathrm{Me}=70 \\
\text { C.V. }=26.1\end{array}$} & \multirow{2}{*}{$\begin{array}{c}51.8 \pm 13.7 \\
\mathrm{Me}=30 \\
\text { C. } \mathrm{V} .=74.8\end{array}$} \\
\hline & & \multicolumn{2}{|c|}{$11(100)$} & & \\
\hline & \multirow{2}{*}{$\begin{array}{c}\text { AR- } \\
\mathrm{n}=49(81.7)\end{array}$} & $30(61.3)$ & $19(38.7)$ & \multirow{2}{*}{$\begin{array}{c}76 \pm 2.7 \\
\mathrm{Me}=80 \\
\text { C.V. }=22.5\end{array}$} & \multirow{2}{*}{$\begin{array}{c}31.6 \pm 5.1 \\
\mathrm{Me}=20 \\
\text { C.V. }=101.6\end{array}$} \\
\hline & & \multicolumn{2}{|c|}{49 (100) } & & \\
\hline
\end{tabular}

Note : Me - median, C.V. - variance coefficient. 
The expression of $\mathrm{Ki}-67$ was $68.9 \pm 6.4 \%$ in $\mathrm{AR}+$ tumors $(\mathrm{Me}=70)$ and $76 \pm 2.7 \%$ in $\mathrm{AR}$ tumors $(\mathrm{Me}=80)$, the difference between these parameters were not statistically significant $(\mathrm{p}>0.05)$ (Table 4).

The difference in the expression of cyclin D1 in AR+ tumors and AR- tumors $(51.8 \pm 13.7 \%$ and $31.6 \pm 5.1 \%$, respectively) was statistically insignificant $(\mathrm{p}>0.05)$. Regardless of the presence or absence of AR in tumors, a high variance coefficient of the level of cyclin D1 indicated high inconsistency in the parameter values (AR+ - C.V.=74.8; AR- - C.V.=101.6) (Table 4). This was the reason for the division of the group of patients with TNBC and different AR status into subgroups with hyperexpression of cyclin D1 and its low level (Table 5).

Table 5. The expression of markers of the cell cycle in TNBC with different androgen status in subgroups with a high and low level of cyclin D1

\begin{tabular}{|c|c|c|c|c|}
\hline \multirow{2}{*}{\multicolumn{2}{|c|}{$\begin{array}{l}\text { AR-status, } \\
\text { abs. }(\%)\end{array}$}} & \multirow{2}{*}{$\begin{array}{l}\text { Subgroup of TNBC by } \\
\text { the level of cyclin D1, } \\
\text { abs. (\%) }\end{array}$} & \multicolumn{2}{|c|}{$\begin{array}{l}\text { Level of expression of IHC-marker, } \\
\qquad(\mathrm{M} \pm \mathrm{m}, \%)\end{array}$} \\
\hline & & & Cyclin D1 & $\mathrm{Ki}-67$ \\
\hline \multirow{6}{*}{ 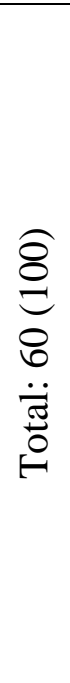 } & \multirow{3}{*}{$\begin{array}{c}\mathrm{AR}+ \\
\mathrm{n}=11(18.3)\end{array}$} & $\begin{array}{c}\text { high } \\
5(45.5)\end{array}$ & $\begin{array}{r}91.3 \pm 4.3 \Delta \\
\mathrm{Me}=90 \\
\text { C. } \mathrm{V} .=8.2\end{array}$ & $\begin{array}{r}71.3 \pm 4.9 \\
\mathrm{Me}=72.5 \\
\text { C.V. }=12\end{array}$ \\
\hline & & $\begin{array}{c}\text { low } \\
6(54.5) \\
\end{array}$ & $\begin{array}{r}20.2 \pm 6.2 \\
\mathrm{Me}=25 \\
\text { C. } \mathrm{V} .=61.2 \\
\end{array}$ & $\begin{array}{r}\mathbf{6 6} \pm \mathbf{1 1 . 7} \\
\mathrm{Me}=70 \\
\text { C.V. }=35.3 \\
\end{array}$ \\
\hline & & \multicolumn{3}{|l|}{ Total: $11(100)$} \\
\hline & \multirow{3}{*}{$\begin{array}{c}\text { AR- } \\
n=49(81.7)\end{array}$} & $\begin{array}{c}\text { high } \\
17(34.7)\end{array}$ & $\begin{array}{r}\mathbf{7 2 . 8} \pm \mathbf{5 . 8 7 \boldsymbol { \Delta }} \\
\mathrm{Me}=70 \\
\text { C. } \mathrm{V} .=29.9 \\
\end{array}$ & $\begin{array}{r}\mathbf{7 3 . 3} \pm \mathbf{5 . 1} \\
\mathrm{Me}=75 \\
\text { C.V. }=25.3\end{array}$ \\
\hline & & $\begin{array}{c}\text { Low } \\
32(65.3)\end{array}$ & $\begin{array}{r}9.4 \pm 1.9 \\
M e=5 \\
\text { C.V. }=102.4\end{array}$ & $\begin{array}{r}79.04 \pm 3 \\
\mathrm{Me}=80 \\
\text { C. } \mathrm{V} .=18.4\end{array}$ \\
\hline & & Total: 49 (100) & & \\
\hline
\end{tabular}

Note: C.V. - variation coefficient, Me - median. The difference between the parameters marked with $\boldsymbol{\Delta}$ is significant $(\mathrm{P}<0.05)$.

In patients with AR+ TNBC, a high and low level of expression of cyclin D1 $(45.5 \%$ and $54.5 \%$, respectively) had a similar rate of occurrence. The level of Ki-67 was not significantly different in the subgroups. In patients with AR-TNBC, the share of tumors with high expression of cyclin D1 was almost two times lower than the share of tumors with low expression $(34.7 \%$ vs $65.3 \%)$.

On average, in patients with $\mathrm{AR}+\mathrm{TNBC}$, hyperexpression of cyclin D1 was significantly higher than in AR- (91.3\% and 72.8\%, respectively), $\mathrm{P}<0.05$ (Table 5). The level of Ki-67 was not significantly different neither in patients with TNBC with different androgen statuses nor in their subgroups with high or low expression of cyclin D1.

Thus, in some patients with TNBC with and without the signs of the basal epithelium, hyperexpression of cyclin D1 was revealed. Hyperexpression of cyclin D1 was registered in 
different tumors and the majority of researchers suggest its negative role in oncogenesis. Increased expression of cyclin D1 in benign tumors can precede its malignization and can be associated with a decrease in the total survival of oncologic patients $[10,12]$. Using non-small cell lung cancer as an example, it was found that hyperexpression of cyclin D1 develops due to the amplification or hyperexpression of PRAD1 gene coding cyclin D1, in turn, the increased expression of cyclin D1 contributes to the initiation of cellular mitosis [14]. The role of cyclin D1 was established in the induction of cellular migration and invasion and enhancement of angiogenesis [15]. There are experimental data that hyperexpression of cyclin D1 enhances the apoptosis induced by radiotherapy and radiosensitivity of breast tumor cells [13].

Although the present study included a few cases with AR+ TNBC, the authors revealed some tendencies. The androgen status did not influence the intensity of proliferative activity in TNBC and hyperexpression of cyclin D1 was observed in both AR+ and AR- tumors. A high level of expression of cyclin D1 in patients with AR+ TNBC was significantly higher than in AR-. Besides, in patients with $\mathrm{AR}+\mathrm{TNBC}$, the majority of tumors were characterized by hyperexpression of cyclin D1. Some studies showed that women with cyclin D1-negative, ER+ BC had better treatment prognosis [10]. Probably, hormonal therapy for androgen will have the same consistency as for AR+ TNBC.

CONCLUSIONS. In patients with BL TNBC, a significantly higher level of expression of a common marker of proliferation Ki-67 was observed in comparison with patients with TNBC that did not have signs of the basal epithelium.

The difference in the mean values of cyclin D1 in these groups was insignificant. The level of cyclin D1 in both groups was very variable and did not correlate with the expression of Ki-67.

The division of the studied TNBC groups into subgroups with a high and low level of the expression of cyclin D1 allowed the authors to establish that some cases of TNBC were characterized by hyperexpression of cyclin D1 that is a marker of the S-phase of the mitotic cycle. A high level of cyclin D1 in BL TNBC was observed rarer than in non-BL TNBC. However, in the first case, its mean value was significantly higher. In cases with a low level of expression of cyclin D1, there were no significant differences between the groups because of the significant variance of the data.

In cases with hyperexpression of cyclin D1, a significantly higher level of Ki-67 remained in patients with BL TNBC in comparison with NC TNBC. In cases with low expression of cyclin D1, the difference was insignificant. The share of tumors with high expression of cyclin D1 was a bit higher among patients with AR+ TNBC. The mean value was significantly higher in comparison with AR- tumors. 


\section{REFERENCES}

1. WHO Newsletter. 2015 [Informatsionnyi biulleten' VOZ. 2015]. Available at: https://www.who.int/bulletin/volumes/93/ru/ (accessed 9 February 2019).

2. Tiuliandin S.A., Stenina M.B., Frolova M.A. Triple negative breast cancer [Troinoi negativnyi rak molochnoi zhelezy]. Practical oncology - Prakticheskaia onkologiia, 2010, vol. 11, no (4, pp. 247252.

3. Perou C.M., Sørlie T., Eisen M.B. et al. Molecular portraits of human breast tumors. Nature, 2000, vol. 406, no 6797, pp. 747-752, doi 10.1038/35021093.

4. Kit O.I., Shatova Iu.S., Frantsiiants E.M. et al. The Path to Personalized Tactics for Breast Cancer Patients [Put' k personifitsirovannoi taktike lecheniia bol'nykh rakom molochnoi zhelezy]. Oncology questions - Voprosy onkologii, 2017. vol. 63, no 5, pp. 719-723.

5. Andre F., Zielinski C. Optimal strategies for metastatic triple negative breast cancer with currently approved agents. Annals of Oncology, 2012, vol. 23, pp. 46-51, doi 10.1093/annonc/mds 195.

6. Todorov S.S., Bosenko E.S., Kuchkina L.P. et al. Biological heterogeneity of triple negative breast cancer [Biologicheskaia geterogennost' troinogo negativnogo raka molochnoi zhelezy]. Eurasian Cancer Journal: mat. IX Congress of Oncologists and Radiologists of CIS and Eurasia (Minsk, June 15-17, 2016) - Evraziiskii onkologicheskii zhurnal: mat. IX S"ezda onkologov i radiologov stran SNG i Evrazii (Minsk, 15-17 iiunia, 2016 g.), 2016, vol. 4, no 2, p. 469.

7. Khramtsov A.I. Opredelenie bazovykh prognosticheskikh markerov raka molochnoi zhelezy $\mathrm{s}$ ispol'zovaniem tekhnologii tkanevykh matrits: dissertatsiia kandidata meditsinskikh nauk [Determination of basic prognostic markers of breast cancer using tissue matrix technologies: the dissertation of candidates of medical sciences], St. Petersburg, 2011, 123 p.

8. Nefedova N.A., Danilova N.V. Clinicopathologic characterization of the subtypes of triple negative breast cancer. [Kliniko-morfologicheskaia kharakteristika podtipov troinogo negativnogo raka molochnoi zhelezy]. Fundamental Research - Fundamental'nye issledovaniia, 2013, no 9, vol. 5, pp. 881-885.

9. Shatova Yu.S., Frantsiyants E.M., Novikova I.A et al. Antiandrogen therapy: a new direction in targeted therapy for breast cancer [Antiandrogennaia terapiia: novoe napravlenie targetnoi terapii raka molochnoi zhelezy]. Modern problems of science and education - Sovremennye problemy nauki $i$ obrazovaniia, 2017, no. 3, available at: https://science-education.ru/article/view?id=26392 (accessed 07.03.2018).

10. Krylov A.Iu., Krylov Iu.V., Ianchenko V.V. Determination of androgen receptors in cells of triple negative breast cancer [Opredelenie androgenovykh retseptorov v kletkakh troinogo negativnogo raka molochnoi zhelezy]. Immunopathology, allergology, infectology - Immunopatologiia, allergologiia, 
infektologiia, 2016, no 1, pp. 32-36, doi 10.14427/jipai.2016.1.32.

11. Shatova Yu.S., Frantsiyants E.M., Novikova I.A. et al. Cyclin D1 and its prognostic significance in planning endocrine therapy in postmenopausal women in breast cancer [Tsiklin D1 i ego prognosticheskaia znachimost' v planirovanii endokrinnoi terapii u zhenshchin postmenopauzal'nogo vozrasta pri rake molochnoi zhelezy] Postgraduate Doctor - Vrach-aspirant, 2012, vol. 50, no 1.3, pp. 401-407.

12. Shulga A.V., Basinski V.A., Savicki S.E. Prognostic significance of expression of cyclines b1 and d1 in case of ovarian carcinoma [Prognosticheskoe znachenie urovnia ekspressii tsiklinov B1 i D1 pri rake iaichnikov]. Health and environmental problems - Problemy zdorov'ia i ekologii, 2009, pp. 57-61.

13. Coco Martin J.M., Balkenende A., Verschoor T. et al. Cyclin D1 overexpression enhances radiation-induced apoptosis and radiosensitivity in a breast tumor cell line. Cancer Research, 1999. vol. 59, no 5, pp. 1134-1140.

14. Tiuliandin S.A., ed by Perevodchikova N.I. Promising drug therapy approaches for non-small cell lung cancer. New in lung cancer therapy (early 21 st century lung cancer therapy) [Perspektivnye podkhody lekarstvennoi terapii nemelkokletochnogo raka legkogo. Novoe v terapii raka legkogo (terapiia raka legkogo nachala XXI veka)]. Available at: https://medi.ru/info/11123/ (accessed 7 March 2018).

15. Pestell R.G. New roles of Cyclin D1. The American Journal of Pathology, 2013, vol. 183, no 1, pp. 3-9, doi 10.1016/j.ajpath.2013.03.001 